\title{
Endo and regioselectivity in 1,3-dipolar cycloaddition of pyridazinium $N$-ylides with a non-symmetrical cyclic olefin
}

\author{
Florea Dumitraşcu, ${ }^{\text {a }}$ Mino R. Caira, ${ }^{\text {,b }}$ Constantin Drăghici, ${ }^{\text {a } M i r o n ~ T e o d o r ~ C a ̆ p r o i u, ~}$ \\ Barbu Miu, ${ }^{c}$ and Loredana Barbu ${ }^{a}$ \\ ${ }^{a}$ Centre of Organic Chemistry "C. D. Nenitzescu", Romanian Academy, Spl. Independentei 202B, \\ Bucharest 060023, Romania \\ ${ }^{b}$ Department of Chemistry, University of Cape Town, Rondebosch 7701, South Africa \\ "National College "I. C. Bratianu", Armand Calinescu 14, Piteşti 110047, Romania \\ E-mail: Mino.Caira@uct.ac.za
}

\begin{abstract}
The 1,3-dipolar cycloaddition between pyridazinium $\mathrm{N}$-ylides $\mathbf{3}$ and 3-methyl- $\mathrm{N}$ phenylmaleimide was studied. In the case of pyridazinium phenacylides 4 a-c the reaction was endo and regioselective, while in the case of carbomethoxymethylide $4 \mathbf{d}$ the cycloaddition gave two endo isomers in a 2:1 ratio. The stereochemistry of the adducts $\mathbf{6 a - c}$ and $7 \mathbf{a}, \mathbf{b}$ was determined by NMR spectroscopy and confirmed by X-ray analysis for a representative compound, namely $\mathbf{6 b}$.
\end{abstract}

Keywords: Pyridazinium $N$-ylides, 1, 3-dipolar cycloaddition, endo and regioselectivity

\section{Introduction}

The 1,3-dipolar cycloaddition reactions of olefinic and acetylenic dipolarophiles with heteroaromatic $\mathrm{N}$-ylides have given rise to interesting problems of stereo- and regioselectivity. ${ }^{1-}$ 13 Cycloaddition reactions between pyridazinium phenacylides and symmetrical N-substituted maleimides were first reported in $1979^{14}$ but the stereochemistry of the ensuing cycloadducts was investigated only more recently. ${ }^{10-13}$ Herein we report the 1,3-dipolar cycloaddition reaction between pyridazinium N-ylides 4 and the non-symmetrical 3-methyl- $N$-phenylmaleimide 5 giving the cycloadducts 6 and 7. 


\section{Results and Discussion}

The starting materials, pyridazinium bromides 3a-c were prepared by $\mathrm{N}$-alkylation of pyridazine 1 with the corresponding 2-bromoacetophenones $\mathbf{2}$ in acetone at room temperature (Scheme 1). The quaternization of pyridazine with methyl bromoacetate was performed in ethyl acetate at reflux, giving the salt $\mathbf{3 d}$.

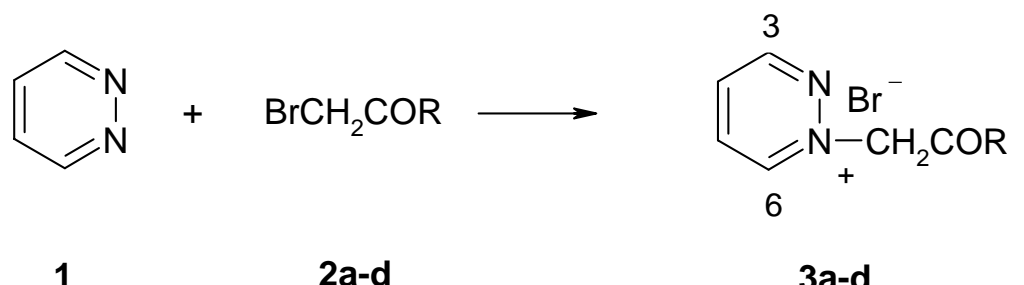

a: $\mathrm{R}=4-\mathrm{ClC}_{6} \mathrm{H}_{4} ; \mathrm{b}: \mathrm{R}=4-\mathrm{BrC}_{6} \mathrm{H}_{4} ; \mathrm{c}: \mathrm{R}=4-\mathrm{NCC}_{6} \mathrm{H}_{4} ; \mathrm{d}: \mathrm{R}=\mathrm{OMe}$

\section{Scheme 1}

The structure of the new cycloimmonium bromide 3c was confirmed by elemental analysis and NMR spectroscopy. The protons H-3 and H-6 are strongly deshielded due to the vicinity of the two nitrogen atoms. Interestingly, in the ${ }^{1} \mathrm{H}-\mathrm{NMR}$ spectra of $\mathbf{3 a - d}$ recorded in $\mathrm{CDCl}_{3}$ and trifluoroacetic acid, the signals for the $\mathrm{H}-3$ and $\mathrm{H}-6$ protons from the pyridazine moiety appeared as eight lines (ddd) and as six lines (dt). The multiplicity of these protons is due to a long range coupling of H-3 with H-6 and was confirmed by a $\mathrm{HH}$ decoupling experiment. The value of this coupling constant was found to be $0.9 \mathrm{~Hz}$. A similar para coupling was found between protons H-1 and H-4 for some phthalazinium salts. ${ }^{15,16}$

The monosubstituted heteroatomic $N$-ylides are generally unstable compounds. Therefore the $\mathrm{N}$-ylides 4a-c were generated in situ by the reaction between the corresponding salts 3a-c and triethylamine in the presence of 3-methyl- $N$-phenylmaleimide as dipolarophile (Scheme 2). The cycloaddition reaction was performed in methylene chloride at room temperature. After 15 minutes, the reaction mixture was washed with water. The crude product was subjected to ${ }^{1} \mathrm{H}-$ NMR measurements, which indicated the formation of cycloadducts 6a-c as single regioisomers.

The regioselectivity of the cycloaddition between pyridazinium phenacylides 4a-c and 3methyl- $N$-phenylmaleimide $\mathbf{5}$ can be explained by steric repulsion between the methyl group in the maleimide (dipolarophile) and the COAr group in the ylide (1,3-dipole). The stereochemistry of the cycloadducts 6a-c was determined by ${ }^{1} \mathrm{H}-\mathrm{NMR}$ spectroscopy, X-ray diffraction and checked by comparison with literature NMR and X-ray data for similar compounds. ${ }^{11,12,17-19}$ 


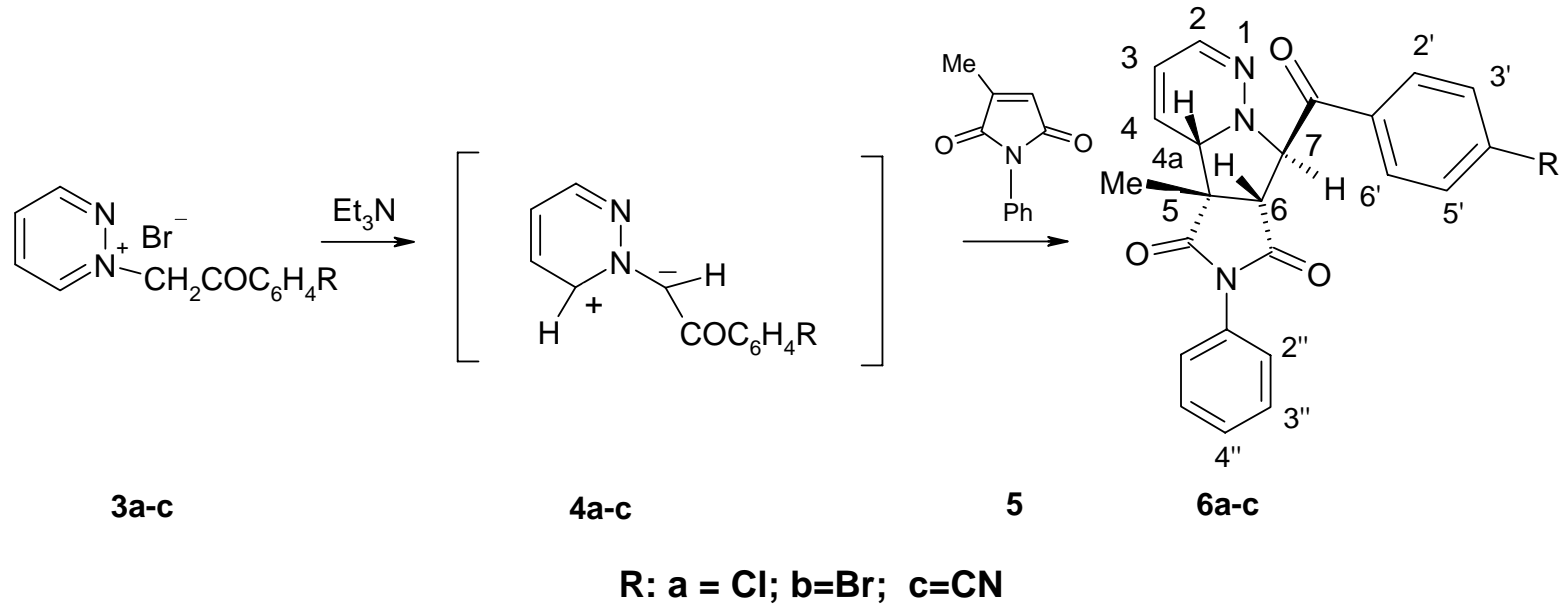

\section{Scheme 2}

The chemical shifts of protons were assigned on the basis of values of coupling constants and HH-COSY. The protons H-6 and H-7 appear in the ${ }^{1} \mathrm{H}-\mathrm{NMR}$ spectrum as two doublets with $J=$ $1.1 \mathrm{~Hz}$, the small value of the vicinal coupling constant indicating a trans configuration. The position of the methyl group on the pyrrolidine moiety was deduced from multiplicity of the signals for protons $\mathrm{H}-4 \mathrm{a}$ and $\mathrm{H}-7$. Thus, $\mathrm{H}-4 \mathrm{a}$ appears as a doublet of doublets instead of a doublet of doublets of doublets, and H-7 as a doublet. The cis configuration of the methyl group with respect to the hydrogen atoms $\mathrm{H}-4 \mathrm{a}$ and $\mathrm{H}-6$ was put in evidence by a NOEDIF experiment. Thus, irradiation of the 5-Me group results in an enhancement in differential spectra for protons H-4a and H-6.

The stereochemistry of the cycloadducts 6a-c shows that the cycloaddition reaction is endo and regioselective. From the trans configuration of the hydrogens on the carbon atoms $\mathrm{C}-4 \mathrm{a}$ and $\mathrm{C}-7$, we can deduce that N-ylides 4a-c participate in the cycloaddition in the anti form.

The signal for $\mathrm{H}-4 \mathrm{a}$ appears as a doublet of doublets with a vicinal coupling constant of 5.4 $\mathrm{Hz}$ and an allylic one of $J=1.3 \mathrm{~Hz}$. The large value of $J_{4,4 \mathrm{a}}$ could be explained by a distortion of the tetrahydro-pyrrolopyridazine system.

Confirmation of the stereochemistry of cycloadducts 6 was established by X-ray analysis of 6b as a representative compound in this series. Table 1 lists relevant crystal data and Figure 1 shows the molecular structure, with thermal ellipsoids drawn at the $40 \%$ probability level. As the crystal is centrosymmetric, it contains both the molecule shown (corresponding to that in Scheme 2) and its enantiomer. 
Table 1. Crystal data and refinement details for the representative compound $6 \mathbf{b}^{\mathrm{a}}$

\begin{tabular}{ll}
\hline Molecular formula & $\mathrm{C}_{23} \mathrm{H}_{18} \mathrm{~N}_{3} \mathrm{O}_{3} \mathrm{Br}$ \\
$M$ & 464.31 \\
Crystal system & Monoclinic \\
Space group & $\mathrm{P}{ }_{1} / \mathrm{n}$ \\
$a / \AA$ & $11.207(2)$ \\
$b / \AA$ & $11.582(2)$ \\
$c / \AA$ & $15.618(3)$ \\
$\beta /{ }^{\circ}$ & $102.74(3)$ \\
$V_{\text {cell }} \AA^{3}$ & $1977.1(7)$ \\
$\mathrm{Z}$ & 4 \\
$\mathrm{~T} / \mathrm{K}$ & $113(2)$ \\
Absorption coefficient $/ \mathrm{mm}^{-1}$ & 2.111 \\
$\mathrm{~F}(000)$ & 944 \\
$\theta$-range/ & $1.00-25.68$ \\
Index ranges & $-13 \leq \mathrm{h} \leq 13,-14 \leq \mathrm{h} \leq 14,-19 \leq \mathrm{h} \leq 19$ \\
Reflections collected & 3753 \\
Observed reflections $[\mathrm{I}>2 \sigma(\mathrm{I})]$ & 3099 \\
Data/restraints/parameters & $3753 / 0 / 273$ \\
Goodness-of-fit on $\mathrm{F}^{2}$ & 1.024 \\
Final R indices $[\mathrm{I}>2 \sigma(\mathrm{I})]$ & $\mathrm{R}_{1}=0.0269, \mathrm{wR}_{2}=0.0601$ \\
$\Delta \rho$ (max., min. $) / \mathrm{e} \AA^{-3}$ & $0.321,-0.357$ \\
\hline
\end{tabular}

${ }^{a}$ Full crystallographic data (CCDC 669283)

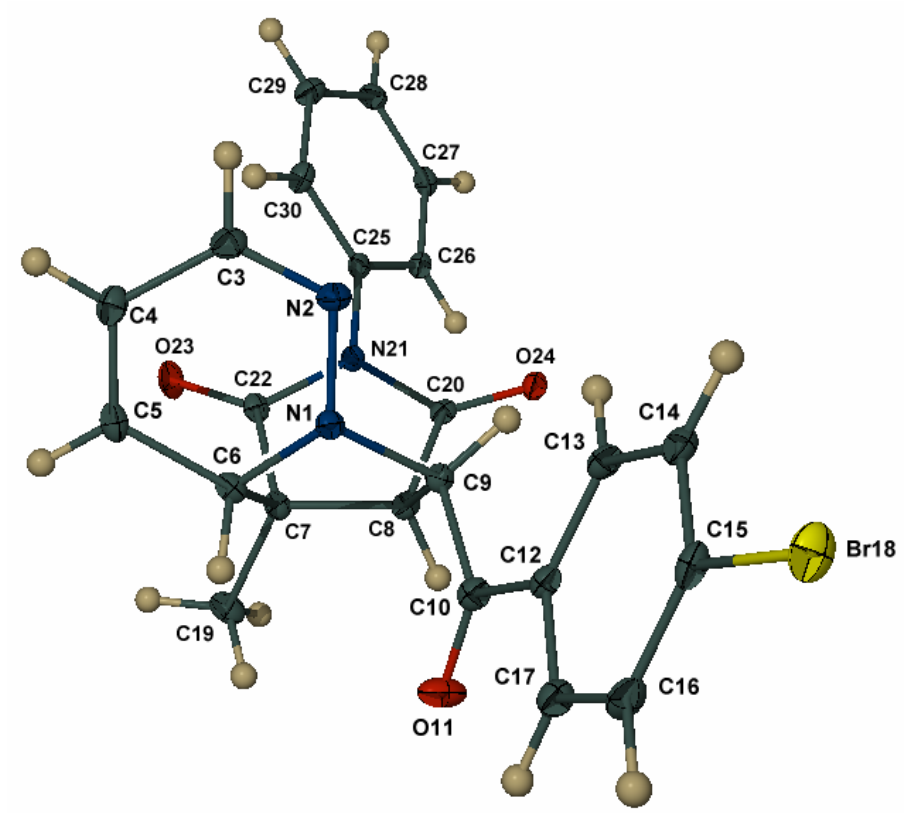

Figure 1. Perspective view of the molecular structure of compound $\mathbf{6 b}$. 
The fused tricyclic system in $\mathbf{6 b}$ adopts a U-shaped conformation. For the pyridazine ring, the formal double bonds indicated in Scheme 2 correspond to N2-C3 and C4-C5, with observed distances $1.292(3)$ and 1.327(3) $\AA$ respectively. The remaining $\mathrm{C}-\mathrm{C}$ bonds are significantly longer (C3-C4 1.456(3), C5-C6 1.500(3) $\AA$ ), as is C6-N1 (1.478(2) $\AA$ ), reflecting their contrasting single bond character. The distance N1-N2 is 1.400(2) $\AA$. The ring adopts a twist conformation with atoms $\mathrm{C} 3 \rightarrow \mathrm{C} 6$ nearly coplanar (dihedral angle C3-C4-C5-C6 2.9(2) ${ }^{\circ}$ ) but with both nitrogen atoms deviating from the plane in the same sense (above the plane in Figure 1) with a dihedral angle $\mathrm{C} 3-\mathrm{N} 2-\mathrm{N} 1-\mathrm{C} 6$ of $32.2(2)^{\circ}$. The central ring of the tricyclic system adopts an envelope conformation (flap at N1), while the second 5-membered ring is planar (max. deviation from the LS plane $=0.028(2) \AA$, for C20). The orientation of the phenyl substituent on $\mathrm{N} 21$ is defined by the dihedral angle $\mathrm{C} 20-\mathrm{N} 21-\mathrm{C} 25-\mathrm{C} 26,52.8(2)^{\circ}$, while the orientation of the bromobenzoyl group relative to the tricyclic system is defined by the combination N1-C9-C10$\mathrm{C} 12=-78.1(2)^{\circ}$ and $\mathrm{C} 9-\mathrm{C} 10-\mathrm{C} 12-\mathrm{C} 13=-13.3(3)^{\circ}$.

The structural features of the tricyclic system in $\mathbf{6 b}$ reported above closely resemble those reported for the related compound endo- $N$-(4-methylphenyl)-3-(4-bromobenzoyl)-1-methyl1,2,3,10b-tetrahydro-pyrrolo[2,1-a]phthalazine-1,2-dicarboximide, obtained by cycloaddition of a phthalazinium phenacylide and the non-symmetrical cyclic olefin 3-methyl-1-(4-methylphenyl) maleimide. ${ }^{19}$

Notably, in the present study, the analogous reaction between methoxycarbonyl pyridazinium N-ylide 4d and 3-methyl- $N$-phenylmaleimide 5 gave a mixture of regioisomers $7 \mathbf{a}$ and $\mathbf{7 b}$, in a ratio of 2:1 (Scheme 3). Unfortunately, the reaction was not complete and the separation of the isomers was unsuccessful. Nevertheless, the stereochemistry of the two regioisomers could be assigned by physical methods.

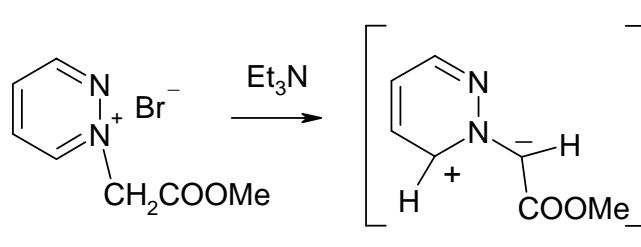

3d

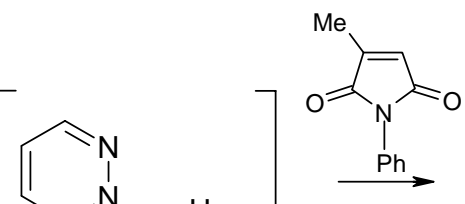

4d

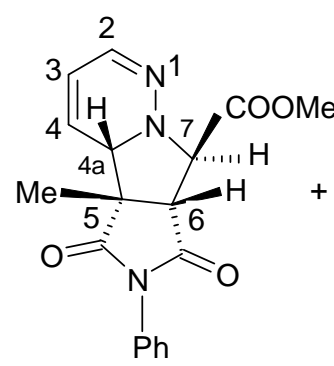

$7 a$

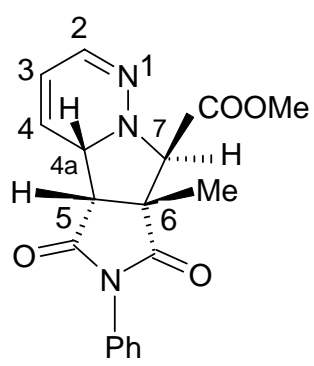

$7 b$

\section{Scheme 3}

The ${ }^{1} \mathrm{H}-\mathrm{NMR}$ data (Figure 2) indicated that the major product, 7a, has a structure similar to those of compounds $\mathbf{6 a - c}$. In the case of the compound $\mathbf{7 b}$, the proton $\mathrm{H}-4 \mathrm{a}(\delta=5.04 \mathrm{ppm})$ appears as eight lines ( $\mathrm{ddd}, J_{4 \mathrm{a}, 5}=8.4 \mathrm{~Hz}, J_{4,4 \mathrm{a}}=3.8 \mathrm{~Hz}, J_{3,4 \mathrm{a}}=2.0 \mathrm{~Hz}$ ), whereas H-5 is a doublet with $J=8.4 \mathrm{~Hz}$. The large value of the coupling constant between H-5 and H-4a indicates a cis configuration. The proton $\mathrm{H}-7$ appears as a sharp singlet $(\delta=4.87 \mathrm{ppm})$. 


\begin{tabular}{|c|c|c|c|c|}
\hline $\mathrm{H}-\mathbf{2}$ & H-4 & $\mathrm{H}-3$ & $11-4 a$ & H-S \\
\hline 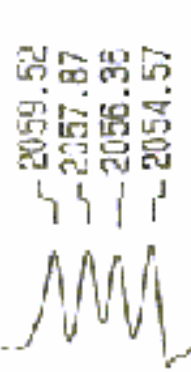 & 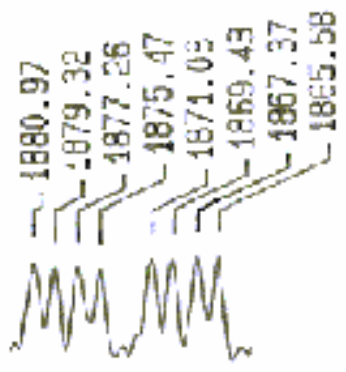 & 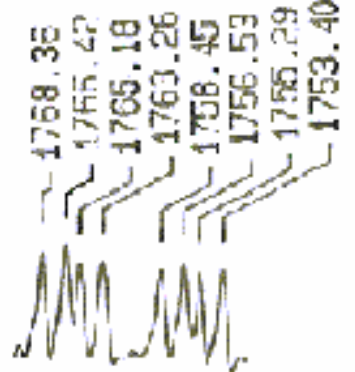 & 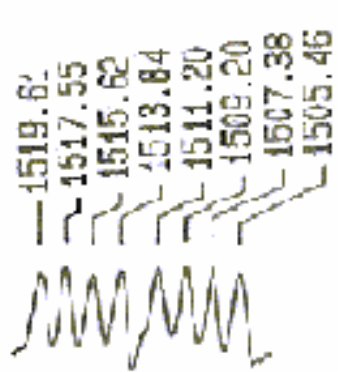 & 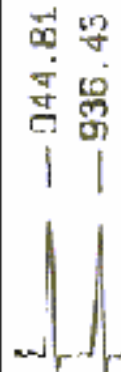 \\
\hline
\end{tabular}

Figure 2. The signals for the representative protons of the regioisomer $\mathbf{7 b}$.

The difference in regioselectivity between the reactions of $\mathbf{4 a - c}$ and $\mathbf{4 d}$ can be explained by the increased steric hindrance of the benzoyl moiety as opposed to that of the methoxycarbonyl group.

\section{Conclusions}

The regioselectivity in the cycloaddition of pyridazinium $\mathrm{N}$-ylides is determined by the nature of the substituent attached to the ylidic carbanion. Thus, when the substituent is COAr, the reaction is completely regioselective, whereas with COOMe as substituent, a mixture of stereoisomers was obtained.

From the stereochemistry of the compounds $\mathbf{6 a - c}$ and $\mathbf{7 a}, \mathbf{b}$ it was possible to conclude that in the cycloaddition reaction the pyridazinium ylides 4a-c participate only in the anti form.

\section{Experimental Section}

General Procedures. Melting points were determined on a Boëtius hot plate and are uncorrected. The NMR spectra were recorded on a Varian Gemini 300 BB instrument, operating at $300 \mathrm{MHz}$ for ${ }^{1} \mathrm{H}$ and $75 \mathrm{MHz}$ for ${ }^{13} \mathrm{C}$. Supplementary evidence was given by HETCOR and COSY experiments.

\section{Synthesis of pyridazinium bromides 3}

$10 \mathrm{Mmol}$ pyridazine and $11 \mathrm{mmol}$ 2-bromoacetophenone 2 in $50 \mathrm{~mL}$ of acetone were stirred at room temperature for 5-6 h. The precipitate was collected on filter paper and washed with acetone. For pyridazinium bromide $3 \mathbf{c}$ the reaction medium was ethyl acetate.

1-[2-(4-Cyanophenyl)-2-oxoethyl]pyridazinium bromide (3c). Colourless crystals from acetonitrile or ethanol with m.p. $225-7{ }^{\circ} \mathrm{C}$; yield $84 \%$. Anal. Calcd. $\mathrm{C}_{13} \mathrm{H}_{10} \mathrm{BrN}_{3} \mathrm{O}: \mathrm{N} 13.82$. 
Found: N 14.07. ${ }^{1} \mathrm{H}-\mathrm{NMR}\left(300 \mathrm{MHz}, \mathrm{CDCl}_{3}+\mathrm{TFA}\right) \delta: 6.73\left(\mathrm{~s}, 2 \mathrm{H}, \mathrm{CH}_{2}\right) ; 7.90(\mathrm{~d}, 2 \mathrm{H}, J=8.6$ Hz, H-3', H-5'); 8.20 (d, 2H, $J=8.6$ Hz, H-2', H-6'); 8.51 (ddd, 1H, J=8.3, 5.0, $1.2 \mathrm{~Hz}, \mathrm{H}-4$ ); 8.78 (ddd, $1 \mathrm{H}, J=8.3,5.8,2.0 \mathrm{~Hz}, \mathrm{H}-5)$; 9.45 (ddd, $1 \mathrm{H}, J=5.0,2.0,0.9 \mathrm{~Hz}, \mathrm{H}-3$ ); 10.05 (dt, $1 \mathrm{H}$, $J=5.9,1.2,0.9 \mathrm{~Hz}, \mathrm{H}-6) .{ }^{1} \mathrm{H}-\mathrm{NMR}\left(300 \mathrm{MHz}, \mathrm{DMSO}-\mathrm{d}_{6}\right) \delta: 6.81\left(\mathrm{~s}, 2 \mathrm{H}, \mathrm{CH}_{2}\right) ; 8.16,8.25(2 \mathrm{~d}$, $4 \mathrm{H}, J=8.6 \mathrm{~Hz}, \mathrm{H}-2^{\prime}, \mathrm{H}-3$ ', H-5', H-6'); 8.77 (ddd, 1H, $J=8.4,5.0,1.3 \mathrm{~Hz}, \mathrm{H}-4$ ); 8.90 (sep, 1H, $J=8.3,5.9,2.0 \mathrm{~Hz}, \mathrm{H}-5) ; 9.75(\mathrm{ddd}, 1 \mathrm{H}, J=5.0,2.0,1.0 \mathrm{~Hz}, \mathrm{H}-3) ; 9.91(\mathrm{dt}, 1 \mathrm{H}, J=5.9,1.3,1.0$ $\mathrm{Hz}, \mathrm{H}-6) .{ }^{13} \mathrm{C}-\mathrm{NMR}\left(75 \mathrm{MHz}, \mathrm{CDCl}_{3}+\mathrm{TFA}\right) \delta: 71.0\left(\mathrm{CH}_{2}\right) ; 116.6,117.7$ (C-4', CN); 129.0 (C-2', C-6'); 123.3 (C-3', C-5'); 136.1 (C-1'); 136.3, 136.8 (C-4, C-5); 152.4154 .0 (C-3, C-6); 189.4 (COAr).

\section{General procedure for synthesis of cycloadducts 6 and 7}

$5 \mathrm{Mmol}$ pyridazinium bromide 3 was suspended in $25 \mathrm{ml}$ of dichloromethane and then $5.0 \mathrm{mmol}$ of maleimide 5 was added. Under vigorous stirring, $0.7 \mathrm{ml}(5 \mathrm{mmol})$ of triethylamine (dissolved in $5 \mathrm{~mL}$ methylene chloride) was added dropwise. After $15 \mathrm{~min}$ the reaction mixture was washed with water and the solvent evaporated. The residue was triturated with ethanol and the precipitate isolated by filtration in the case of compounds 6a-c.

endo- $N$-Phenyl-7-(4-chlorobenzoyl)-5-methyl-4a,5,6,7-tetrahydropyrrolo[1,2-b]pyridazine5,6-dicarboximide (6a). The product was recrystallized from ethanol and colourless crystals with mp 163-5 ${ }^{\circ} \mathrm{C}$ were obtained; yield $85 \%$. Anal. Calcd. $\mathrm{C}_{23} \mathrm{H}_{18} \mathrm{ClN}_{3} \mathrm{O}_{3}$ : C 65.80; $\mathrm{H} 4.32 ; \mathrm{Cl}$ 8.44; N 10.01. Found: C 66.07; H 4.61; Cl 8.77; N 10.24. ${ }^{1} \mathrm{H}-\mathrm{NMR}\left(300 \mathrm{MHz}, \mathrm{CDCl}_{3}\right) \delta: 1.60$ (s, 3H, Me); 3.70 (d, 1H, J=1.1 Hz, H-6); $3.82(\mathrm{dd}, 1 \mathrm{H}, J=5.4,1.3 \mathrm{~Hz}, \mathrm{H}-4 \mathrm{a}) ; 5.87$ (d, $1 \mathrm{H}, J=$ $1.1 \mathrm{~Hz}, \mathrm{H}-7) ; 5.88$ (ddd, 1H, $J=9.9,3.4,1.3 \mathrm{~Hz}, \mathrm{H}-3$ ); 6.21 (ddd, 1H, $J=9.9,5.4,1.7 \mathrm{~Hz}, \mathrm{H}-4$ ); 6.82 (dd, 1H, J= 3.4, 1.7 Hz, H-2); 7.19-7.22 (m, 2H, H-2", H-6"); 7.38-7.49 (m, 5H, H-3", H4", H-5", H-3', H-5') ; 8.13 (d, 2H, $J=8.6 \mathrm{~Hz}, \mathrm{H}-2$ ', H-6'). ${ }^{13} \mathrm{C}-\mathrm{NMR}\left(75 \mathrm{MHz}, \mathrm{CDCl}_{3}\right) \delta: 19.1$ (Me); 51.2 (C-6); 57.6 (C-5); 63.6 (C-4a); 76.2 (C-7); 117.8 (C-3); 125.9 (C-2", C-6"); 126.0 (C4); 128.6 (C-4"); 129.0, 131.0 (C-2', C-3', C-5', C-6'); 129.2 (C-3", C-5"); 131,9 (C-1"); 132.3 (C-1'); 136.3 (C-2); 140.5 (C-4'); 176.2, 177.5 (2CON); 192.6 (COAr).

endo- $N$-Phenyl-7-(4-bromobenzoyl)-5-methyl-4a,5,6,7-tetrahydropyrrolo[1,2-b]pyridazine5,6-dicarboximide (6b). The product was recrystallized from a mixture of ethanol and acetonitrile and pale-yellow crystals with mp $162-4{ }^{\circ} \mathrm{C}$ were obtained; yield $82 \%$. Anal. Calcd. $\mathrm{C}_{23} \mathrm{H}_{18} \mathrm{BrN}_{3} \mathrm{O}_{3}$ : C 59.50; $\mathrm{H}$ 3.91; $\mathrm{Br} 17.21 ; \mathrm{N}$ 9.05. Found: $\mathrm{C} 59.50 ; \mathrm{H} 4.18 ; \mathrm{Br} 17.60 ; \mathrm{N} 9.27$. ${ }^{1} \mathrm{H}-\mathrm{NMR}\left(300 \mathrm{MHz}, \mathrm{CDCl}_{3}\right) \delta: 1.60$ (s, 3H, Me); 3.71 (d, 1H, $\left.J=1.1 \mathrm{~Hz}, \mathrm{H}-6\right) ; 3.83$ (dd, 1H, $J=$ 5.4, $1.3 \mathrm{~Hz}, \mathrm{H}-4 \mathrm{a}) ; 5.87$ (d, 1H, $J=1.1 \mathrm{~Hz}, \mathrm{H}-7$ ); 5.88 (ddd, 1H, J=9.9, 3.4, $1.2 \mathrm{~Hz}, \mathrm{H}-3$ ); 6.22 (ddd, 1H, $J=9.9,5.4,1.6 \mathrm{~Hz}, \mathrm{H}-4) ; 6.83$ (dd, 1H, $J=3.4,1.6 \mathrm{~Hz}, \mathrm{H}-2)$; 7.20-7.23 (m, 2H, H-2", H-6"); 7.38-7.49 (m, 3H, H-3", H-4", H-5"); 7.65 (d, 2H, J=8.6 Hz, H-3', H-5' ); 8.06 (d, 2H, J $\left.=8.6 \mathrm{~Hz}, \mathrm{H}-2{ }^{\prime}, \mathrm{H}-6{ }^{\prime}\right) .{ }^{13} \mathrm{C}-\mathrm{NMR}\left(75 \mathrm{MHz}, \mathrm{CDCl}_{3}\right) \delta: 19.1(\mathrm{Me}) ; 51.3(\mathrm{C}-6) ; 57.6(\mathrm{C}-5)$; $63.6(\mathrm{C}-$ 4a); 76.2 (C-7); 117.8 (C-3); 126.0 (C-2", C-6");126.1 (C-4); 128.7 (C-4"); 129.2 (C-3", C-5"); 129.4(C-4'); 131.0, 132.0 (C-2', C-3', C-5', C-6'); 131.9 (C-1"); 132.8 (C-1'); 136.3 (C-2); 176.2, 177.6 (2CON); 192.8 (COAr). 
endo- $N$-Phenyl-7-(4-cyanobenzoyl)-5-methyl-4a,5,6,7-tetrahydropyrrolo[1,2-b]pyridazine5,6-dicarboximide $(\mathbf{6 c})$. The product was recrystallized from ethyl acetate or methanol and colourless crystals with mp $185-8{ }^{\circ} \mathrm{C}$ were obtained; yield $82 \%$. Anal. Calcd. $\mathrm{C}_{24} \mathrm{H}_{18} \mathrm{~N}_{4} \mathrm{O}_{3}$ : C 70.23; H 4.42; N 13.65. Found: C 70.65; H 4.77; N 13.92. ${ }^{1} \mathrm{H}-\mathrm{NMR}\left(300 \mathrm{MHz}, \mathrm{CDCl}_{3}\right) \delta: 1.62$ (s, 3H, Me); 3.73 (d, 1H, J=1.1 Hz, H-6); 3.79 (dd, 1H, J=5.4, $1.3 \mathrm{~Hz}, \mathrm{H}-4 \mathrm{a}) ; 5.89$ (d, $1 \mathrm{H}, J=$ $1.1 \mathrm{~Hz}, \mathrm{H}-7)$; 5.90 (ddd, 1H, $J=9.9,3.4,1.2 \mathrm{~Hz}, \mathrm{H}-3) ; 6.23$ (ddd, 1H, $J=9.9,5.4,1.7 \mathrm{~Hz}, \mathrm{H}-4$ ); 6.85 (dd, 1H, J=3.4, 1.7 Hz, H-2); 7.20-7.23 (m, 2H, H-2", H-6"); 7.39-7.50 (m, 3H, H-3", H4", H-5") ; 7,81 (d, 2H, J=8.2 Hz, H-3', H-5'); 8.30 (d, 2H, J=8.2 Hz, H-2', H-6'). ${ }^{13} \mathrm{C}-\mathrm{NMR}$ $\left(75 \mathrm{MHz}, \mathrm{CDCl}_{3}\right)$ \&: $19.1(\mathrm{Me}) ; 51.5(\mathrm{C}-6) ; 57.7$ (C-5); 63.9 (C-4a); 76.3 (C-7); 117.0, 117.7 (CN, C-4"); 117.9 (C-3); 126.0 (C-2", C-6");126.1 (C-4); 128.9 (C-4"); 129.3 (C-3", C-5"); 130.0, 132.5 (C-2', C-3', C-5', C-6'); 131.9 (C-1"); 131.8 (C-1'); 136.9 (C-2); 176.1, 177.6 (2CON); 192.5 (COAr).

endo- $N$-Phenyl-7-carbomethoxy-5-methyl-4a,5,6,7-tetrahydropyrrolo[1,2-b]pyridazine-5,6dicarboximide (7a). ${ }^{1} \mathrm{H}-\mathrm{NMR}\left(300 \mathrm{MHz}, \mathrm{CDCl}_{3}\right) \delta: 1.53(\mathrm{~s}, 3 \mathrm{H}, 5-\mathrm{Me}) ; 3.39(\mathrm{~d}, 1 \mathrm{H}, J=1.0 \mathrm{~Hz}$, H-6); 3.84 (s, 3H, OMe); 4.14 (dd, 1H, $J=4.4,1.3 \mathrm{~Hz}, \mathrm{H}-4 \mathrm{a}) ; 5.00$ (d, 1H, J=1.1 Hz, H-7); 5.90 (ddd, $1 \mathrm{H}, J=9.9,3.4,1.3 \mathrm{~Hz}, \mathrm{H}-3) ; 6.26$ (ddd, 1H, $J=9.9,4.4,1.6 \mathrm{~Hz}, \mathrm{H}-4) ; 6.83$ (dd, 1H, $J=3.3,1.6$ Hz, H-2); 7.19-7.22 (m, 2H, H-2", H-6"); 7.38-7.47 (m, 3H, H-3", H-4", H-5").

endo- $N$-Phenyl-7-carbomethoxy-6-methyl-4a,5,6,7-tetrahydropyrrolo[1,2-b]pyridazine-5,6dicarboximide (7b). ${ }^{1} \mathrm{H}-\mathrm{NMR}\left(300 \mathrm{MHz}, \mathrm{CDCl}_{3}\right) \delta: 1.48(\mathrm{~s}, 3 \mathrm{H}, 6-\mathrm{Me}) ; 3.15(\mathrm{~d}, 1 \mathrm{H}, J=8.4 \mathrm{~Hz}$, $\mathrm{H}-5) ; 3.84$ (s, 3H, OMe); 4.87 (s, 1H, H-7); 5.04 (ddd, 1H, J=8.4, 3.8, 2.0 Hz, H-4a); 5.87 (ddd, $1 \mathrm{H}, J=9.9,3.2,2.0 \mathrm{~Hz}, \mathrm{H}-3) ; 6.24$ (ddd, $1 \mathrm{H}, J=9.9,3.8,1.8 \mathrm{~Hz}, \mathrm{H}-4) ; 6.86$ (dd, $1 \mathrm{H}, J=3.2$, 1.8 Hz, H-2); 7.19-7.22 (m, 2H, H-2", H-6"); 7.38-7.47 (m, 3H, H-3", H-4", H-5").

\section{X-ray analysis of compound $6 b$}

A crystal of dimensions $0.12 \times 0.14$ × $0.16 \mathrm{~mm}$ was mounted on a Nonius Kappa CCD diffractometer and cooled in a stream of nitrogen vapor during intensity data-collection. The latter was based on strategies suggested by program $\operatorname{COLLECT}^{20}$ and involved $\phi$-scans of $1-2^{\circ}$ and $\omega$-scans of $2^{\circ}$. DENZO-SMN ${ }^{21}$ was used for data-reduction and unit cell refinement. Lorentz-polarization and empirical absorption corrections were applied to the intensity data and the structure was routinely solved by direct methods (SHELXS-97) ${ }^{22}$ and refined by full-matrix least-squares against $F^{2}$ (SHELXL-97). ${ }^{23}$ All H atoms were located in difference electron density maps but were added in idealized positions in a riding model with $U_{\text {iso }}$ set at 1.2-1.5 times those of their parent atoms. All non-H atoms refined anisotropically. Weights of the form $\mathrm{w}=\left[\sigma^{2}\left(\mathrm{~F}_{\mathrm{o}}{ }^{2}\right)\right.$ $\left.+(\mathrm{aP})^{2}+\mathrm{bP}\right]^{-1}$ with $\mathrm{P}=\left[\max \left(\mathrm{F}_{\mathrm{o}}^{2}, 0\right)+2 \mathrm{~F}_{\mathrm{c}}^{2}\right] / 3$ were employed in the refinement.

\section{Acknowledgements}

MRC wishes to thank the University of Cape Town and the NRF (Pretoria) for research support. 


\section{References}

1. Padwa, A. 1,3-Dipolar Cycloaddition Chemistry, Padwa, A., Ed., Vol. 2. Chap. 12, pp 277-406; Chap. 13, pp 407-406, John Wiley \& Sons: New York, 1984.

2. Klamann, D.; Hageman H. "Organische Stickstoff-Verbindungen mit einer C,NDoppelbindung", Houben-Weyl, Thieme: Stuttgart, New-York, 1991; Vol. E-14b, pp 100-160.

3. Kutsuma T.; Sekine, Y.; Fujiyama, K.; Kobayashy, Y. Chem. Pharm. Bull. 1972, 20, 2701.

4. $\quad$ Kobayashy, Y.; Kutsuma T.; Sekine, Y. Tetrahedron Lett. 1972, 3325.

5. $\quad$ Butler, R. N.; Farrell, D. M.; Pyne, C. S.; J. Chem. Research (S) 1996, 418.

6. Dumitraşcu, F.; Mitan, C. I.; Drăghici, C.; Căproiu, M. T.; Răileanu, D. Tetrahedron Lett. 2001, 42, 8379 .

7. Bachowska, B; Zujewska, T. Arkivoc 2001, (vi), 77.

8. Dumitraşcu, F.; Mitan, C. I.; Drăghici, C.; Căproiu, M. T.; Rev. Roum. Chim. 2002, 47, 881.

9. Elender, K.; Noth, H.; Riebel, P.; Weber, A.; Sauer, J. Tetrahedron 2000, 56, 5443.

10. Tsuge, O.; Kanemasa, S.; Takenaka, S. Chem. Lett. 1985, 14, 355.

11. Tsuge, O.; Kanemasa, S.; Takenaka, S. Bull. Chem. Soc. Jpn. 1985, 58, 3320.

12. Tsuge, O.; Kanemasa, S.; Takenaka, S. Bull. Chem. Soc. Jpn. 1985, 58, 3137.

13. Caproşu, M.; Butnariu, R.; Mangalagiu, I. Heterocycles 2005, 65, 1871.

14. Caproşu, M.; Ungureanu, M.; Druța, I.; Stavri, N.; Petrovanu, M. Bull. Inst. Politehic. Iaşi, Sect. 2, 1979, 25, 79; Chem. Abstr. 1980, 92, 198338g.

15. Dumitraşcu, F.; Mitan, C. I.; Căprău, D.; Drăghici, C.; Căproiu, M. T.; Dumitrescu, D. Rev. Chim. (Bucharest) 2002, 53, 736.

16. Dumitraşcu, F.; Mitan, C. I.; Drăghici, C.; Căproiu, M. T.; Căprău, D.; Dumitrescu, D. Rev. Roum. Chim. 2002, 47, 309.

17. Butler, R. N.; Farrell, D. M.; Pyne, C. S. J. Chem. Research (S) 1998, 214.

18. Butler, R. N.; Coyne, A. G.; McArdle, P.; Cunningham D.; Burke, L. A. J. Chem. Soc., Perkin Trans. 1 2001, 1391.

19. Dumitraşcu, F.; Caira, M. R.; Drăghici, C.; Barbu, L. Anal. Sci. 2005, 21, x133.

20. Hooft, R. COLLECT, 1998, Nonius B.V.:Delft, The Netherlands.

21. Otwinowski, Z., Minor, W. Methods Enzymol. 1997, 276, 307.

22. Sheldrick, G. M. SHELXS-97 1997, (University of Göttingen, Germany).

23. Sheldrick, G. M. SHELXL-97 1997, (University of Göttingen, Germany). 